\title{
The Impact of Regional Investment Liberalization on Foreign Direct Investment: A Firm-level Simulation Assessment
}

\author{
Kiyoyasu Tanaka (Corresponding author) \\ Affiliation: Institute of Developing Economies, JETRO \\ Address: 3-2-2 Wakaba, Mihama-ku, Chiba-shi, Chiba 261-8545, Japan \\ Email: kiyoyasu_tanaka@ide.go.jp \\ Tel: 81-43-299-9755 \\ Fax: 81-43-299-9763 \\ Shawn Arita \\ Affiliation: Economic Research Service, USDA \\ Address: 355 E Street SW, Washington, D.C., USA \\ Email: ssarita@ers.usda.gov \\ Tel:1-202-694-5102 \\ Fax: 1-202-245-4779
}

\begin{abstract}
:
With the proliferation of regional economic integration, investment liberalization has gained in importance. This paper conducts counterfactual policy experiments to simulate the response of multinational firms to a regional decline in investment costs. We find evidence of investment creation effects at the aggregate level. While there is weak evidence of investment diversion effects, the non-participation in regional integration discourages multinational activity of non-member countries. As less productive firms experience the extensive-margin growth strongly, the effects differ significantly by multinational firms with heterogeneous productivity.
\end{abstract}

Keywords: Regional integration, Investment liberalization, FDI, Firm heterogeneity, Japan

JEL Classification: F15, F21, F23 


\section{Introduction}

Recent decades have seen the proliferation of regional economic integration. The number of regional trade agreements (RTAs) has grown since the early 1990s. According to the World Trade Organization (WTO), 398 RTAs notified to the GATT/WTO were in force as of January 2015. In addition to tariff reductions, the scope of recent RTAs has been extended to not only the protection of foreign direct investment (FDI), but investment liberalization for foreign firms. For example, the Association of South East Asian Nations (ASEAN) signed the ASEAN Investment Guarantee Agreement (AIGA) in 1987 to provide a legal framework for investor protection, including adequate compensation for expropriation and an investor-state dispute settlement mechanism. In 2009, the ASEAN Comprehensive Investment Agreement (ACIA) was signed to cover provisions on national and most-favored-nation treatment. By adopting a single negative-list approach, this agreement aims to eliminate foreign-ownership restrictions in a wide range of industries within the ASEAN member countries. Thus, the level and scope of investment liberalization has expanded in the process of regional integration.

In this study, we seek to investigate the impact of regional investment liberalization on FDI activity by simulating the response of multinational firms to a regional decline in investment costs. Regional investment liberalization serves to reduce investment costs for foreign investors between partner countries, but keeps these costs unchanged for those in non-partner countries. As a result, discriminatory investment liberalization could promote FDI within the integrating region, partly through production shifting, at the expense of FDI within the non-integrating region (Baldwin et al., 1999; Blomström and Kokko, 1997). With the proliferation of RTAs, it is crucial to quantitatively assess 
these economic impacts on multinational firms. Additionally, multinational firms with heterogeneous productivity self-select to invest in different foreign markets and to engage in different production levels (Yeaple, 2009; Chen and Moore, 2010). Although we predict heterogeneous responses of individual multinationals to regional integration, the role of firm heterogeneity has received little attention in the empirical investigation on regional investment liberalization.

Regional integration is an aggregate shock that occurs in specific markets and affects FDI decisions of individual firms differently, implying that we need to link aggregate shocks with firm-level responses. With observable data on RTAs and FDI, it is challenging to identify a causal effect on individual multinational firms. To this end, we adopt a structural approach to conduct a series of counterfactual experiments in a general equilibrium framework. Specifically, we draw on our prior work in Arita and Tanaka (2014), which calibrates the firm-heterogeneity model of Eaton, Kortum, and Kramarz (2011, EKK hereafter) to match data on Japanese multinational firms. The calibrated model enables us to examine counterfactual changes in FDI activity of Japanese firms resulting from regional integration. While a counterfactual analysis in Arita and Tanaka (2014) is limited to a global decline in FDI barriers, this paper makes an empirical contribution by investigating how multinational firms respond to a change in FDI barriers in a variety of integrating and non-integrating countries.

In designing policy experiments, we divide 43 sample economies into North and South according to the World Bank Income Classification. We first consider policy experiments in which Japan participates in regional integration with all other economies (North-South), North economies (North-North), and South economies (North-South). In these experiments, multinationals are headquartered in the integrating region. Second, 
we consider policy experiments in which Japan does not participate in each type of regional integration among other economies. In these cases, multinationals are headquartered outside the integrating region. Comparing these experiments, we can illustrate whether the participation of a headquarters country in regional integration affects multinational activity headquartered in that country. Additionally, we separately examine fixed and variable costs of foreign production to shed light on the type of investment liberalization in regional integration. Therefore, our counterfactual analysis provides comprehensive implications of regional investment liberalization.

The main results can be summarized as follows. Regional investment liberalization encourages the entry and local production of foreign firms within integrating economies, consistent with investment creation effects. The non-participation of a headquarters country in regional integration discourages the FDI activity of its firms because of increased competition abroad from other integrating economies. However, multinational activity in non-integrating economies does not decrease substantially, implying weak evidence of investment diversion effects through production shifting from non-integrating to integrating economies. Additionally, multinational firms with heterogeneous productivity respond differently to regional integration in terms of the extensive and intensive margins; the extensive margin is an establishment of foreign production and the intensive margin is the average size of foreign production. While less productive firms could benefit strongly in terms of the extensive-margin growth, the non-participation of a headquarters country could yield a stronger negative impact on them.

With the proliferation of RTAs, there are a growing number of related studies on the impact of RTAs on FDI. Theoretical studies such as Motta and Norman (1996), Montout 
and Zitouna (2005), Ranjan (2006), and Kim (2007) examine the impact of economic integration on FDI and trade in a three-country setting. Despite some variations in assumptions, these studies demonstrate that regional integration induces firms in a non-integrated country to set up a plant in an integrated country. In addition, integrating countries are more likely than the non-integrating country to gain from FDI creation. These results are derived by relating an intra-regional reduction in trade costs to firm-level decisions between FDI and export in serving regional markets. In contrast, our study relates an intra-regional decline in investment costs to firm-level decisions regarding whether or not and how much to produce across integrating and non-integrating markets.

Empirical studies have generally shown that RTAs have a positive impact on FDI in integrating areas. Baldwin et al. (1999) is a pioneering work to simulate investment creation and diversion due to the 1989 Single Market program in the European Union (EU). They find that discriminatory liberalization causes production shifting from non-integrating to integrating regions because of a change in rental rates across regions. Consistent with the results, Barrell and Pain (1999) show that U.S. manufacturing FDI increased in the four largest EU economies after 1989. In the case of NAFTA, MacDermott (2007) shows an increase in FDI flows to member countries after the signature of NAFTA. Tekin-Koru and Waldkirch (2010) further demonstrate that intra-regional FDI increased within the member countries; that is, FDI from the U.S. and Canada to Mexico increased. Moreover, Park and Park (2008) find a positive impact of RTAs on inward FDI in East Asia. While these empirical studies shed light on aggregate FDI in integrating countries, we further examine whether the impact of 
regional integration on FDI differs across heterogeneous firms. ${ }^{1}$

It must be mentioned that we focus on firm-level decisions regarding foreign production, thereby leaving out other aspects of economic integration. Specifically, we do not consider the effects of market expansion and a decline in intra-regional trade costs within an integrating region. ${ }^{2}$ These effects should affect export-platform FDI originating from a non-integrating region because multinational firms have an incentive to locate a production plant in the low-cost integrated market and export to other integrating markets (Motta and Norman, 1996). While such FDI strategies have been theoretically examined by prior studies such as Ekholm et al. (2007), Grossman et al. (2006), and Yeaple (2003), the impact of regional integration on complex FDI strategies is empirically investigated by Baltagi et al. (2008) using a spatial econometric approach. Regarding market expansion effects, Altomonte (2007) and Chen (2009) show that regional integration enhances the market potential of participating economies, thereby attracting more FDI from a non-participating country.

The rest of this paper is organized as follows. Section 2 summarizes a methodological framework for conducting a counterfactual analysis. Section 3 describes the setup of counterfactual policy experiments. In Section 4, we present the benchmark results of regional integration across policy experiments, followed by the results of policy experiments that distinguish variable and fixed costs in regional integration. Section 5 concludes.

\footnotetext{
${ }^{1}$ For welfare analysis of regional integration, Ranjan (2006) finds welfare-improving effects of RTAs in an integrated area based on a three-country model with horizontal multinational activity. Egger et al. (2007) present a comprehensive welfare analysis of trade and investment liberalization in the two-country model with knowledge capital by Markusen (2002).

${ }^{2}$ Prior work such as Kitwiwattanachai et al. (2010) adopts a computable general equilibrium model to analyze the impact of RTAs in a wide range of industries.
} 


\section{Methodological Framework}

This section presents a methodological framework for counterfactual experiments based on the work in Arita and Tanaka (2014). We discuss the key elements of the framework that closely follows EKK (2011). More details are explained in Appendix A. Based on the EKK model of heterogeneous firms in international trade, we allow firms to serve foreign markets solely via local production. By excluding the role of trade, we preclude a variety of alternative choices for firms in serving abroad. ${ }^{3}$ Nevertheless, this simplification enables us to avoid complex firm-level decisions about internationalization and to focus on the choice between home and foreign production.

The EKK model is based on the monopolistic competition framework. Goods are differentiated, and a single firm produces a unique good $j$ with efficiency $z_{i}(j)$. There are $N$ countries that have a continuum of potential producers. A firm in home country $i$ that invests and produces in host country $n$ will incur unit costs as follows:

$$
c_{n i}(j)=\frac{w_{n} d_{n i}}{z_{i}(j)}
$$

where $w_{n}$ is the factor cost in country $n$ and $d_{n i}$ is an iceberg form of efficiency loss, such as the management costs incurred by local plants in implementing production technology abroad. A firm incurs no additional cost in implementing its production technology at home. Since each firm receives a random productivity draw from a Pareto distribution, a measure of potential producers with efficiency of at least $\mathrm{z}$ is as follows:

$$
\mu_{\mathrm{i}}^{\mathrm{Z}}(\mathrm{Z} \geq \mathrm{z})=\mathrm{T}_{\mathrm{i}} \mathrm{z}^{-\theta}, \mathrm{z}>0
$$

where $T_{i}$ is the average level of efficiency in country $i$. The parameter $\theta$ is a distribution parameter of firm productivities for $\theta>0$.

\footnotetext{
${ }^{3}$ As multinational firms may engage in exports, Irarrazabal et al. (2013) consider intra-firm trade between parents and their foreign affiliates, whereas Tintelnot (2012) examines exports of foreign affiliates.
} 
Each country has the standard CES (constant elasticity of substitution) preferences over differentiated goods with the elasticity of substitution between any two goods given by $\sigma>1$. We obtain the following demand function:

$$
X_{n}(j)=\alpha_{n}(j)\left(\frac{p_{n}(j)}{P_{n}}\right)^{-(\sigma-1)} X_{n},
$$

where $X_{n}(j)$ is the sales by firm $j$ in country $n, X_{n}$ is the aggregate demand for manufacturing varieties, and $P_{n}$ is the CES price index. We assume that $\theta-1>\sigma$. $\alpha_{n}(j)$ is an unobservable demand shock for firm $j$ selling in country $n$. A firm $j$ enters market $n$ by paying a fixed cost to establish a production plant as follows:

$$
E_{n i}(j)=E_{n i} \varepsilon_{n}(j)
$$

where $E_{n i}$ is the general fixed cost, such as administrative setup costs, that is constant for all firms. $\varepsilon_{n}(j)$ is an idiosyncratic fixed cost specific to firm $j$ entering market $n$. In this setting, firm $j$ from country $i$ will generate the following net profits in market $n$ :

$$
\pi_{n i}(j)=\left(1-\frac{c_{n i}(j)}{p_{n}(j)}\right) \alpha_{n}(j)\left(\frac{p_{n}(j)}{P_{n}}\right)^{-(\sigma-1)} X_{n}-E_{n i} \varepsilon_{n}(j)
$$

With monopolistic competition and Dixit-Stiglitz preferences, each firm maximizes its profit by charging a constant markup $\bar{m}=\sigma /(\sigma-1)$ over its unit cost $c_{n i}(j)$ such that $p_{n}(j)=\bar{m} c_{n i}(j)$. Its total gross profit is proportional to demand with a factor of $1 / \sigma$, yielding $X_{n}(j) / \sigma$. Thus, firm $j$ will enter market $n$ if and only if its operating profit is sufficient to overcome the fixed entry cost as follows:

$$
\eta_{n}(j)\left(\frac{p_{n}(j)}{P_{n}}\right)^{-(\sigma-1)} \frac{X_{n}}{\sigma} \geq E_{n i}
$$

where $\eta_{n}(j)=\alpha_{n}(j) / \varepsilon_{n}(j)$ is an entry shock to firm $j$ that invests in market $n$.

From equation (6), the entry hurdle condition shows that firm $j$ in country $i$ enters the market if and only if its unit cost is less than the threshold entry cost as follows:

$$
c_{n i}(j) \leq \bar{c}_{n i}(j)
$$


where

$$
\bar{c}_{n i}(j)=\left(\eta_{n}(j) \frac{X_{n}}{\sigma E_{n i}}\right)^{1 /(\sigma-1)} \frac{P_{n}}{\bar{m}} .
$$

A lower value of $\bar{c}_{n i}(j)$ indicates a less attractive market for multinational production. Substituting the constant markup price and equation (8) into equation (3), we express the latent sales conditional on entry as follows:

$$
X_{n i}(j)=\frac{\alpha_{n}(j)}{\eta_{n}(j)} \sigma E_{n i}\left(\frac{\bar{c}_{n i}(j)}{c_{n}(j)}\right)^{\sigma-1}
$$

Conditional on entry, equation (9) dictates the volume of sales by firms in that market. Equations (7), (8), and (9) provide the main predictions about the structure of heterogeneous multinational firms. That is, firms with high productivity are more likely than those with low productivity to (i) invest in a larger number of markets, (ii) penetrate the less attractive markets, and (iii) yield larger sales per market.

The model is re-specified to express the entry and sales conditions governed by four structural parameters including heterogeneity in observed sales, variance in sales, variance in entry shocks, and their correlation. To calibrate the model to match firm-level data on Japanese multinational firms in manufacturing for 2006, a simulated method of moments is used to estimate a set of optimal structural parameters. Appendix shows the estimates of structural parameters used in counterfactual simulations.

To conduct counterfactuals, we account for adjustments of aggregate prices and wages that take place following an exogenous change in FDI barriers. We modify the general equilibrium in EKK (2011) to set up a model in which producers serve their home country by domestic production and foreign countries through FDI. Each country is endowed with labor, which is mobile within countries, but immobile across countries. Intermediates are a Cobb-Douglas combination of labor and intermediates. Final output 
is non-traded and a Cobb-Douglas combination of manufactures and labor. Fixed cost for FDI is paid by labor. Profits accrue to the headquarter country of producers. As consumers own equal shares of each firm headquartered in their country, the profits are redistributed equally among the consumers. A country's GDP is equal to its total wage from production in its own country and its total profit from abroad. Lastly, some countries are net receivers for FDI, and we allow for FDI deficits. The general equilibrium is set up such that manufacturing production and consumption across countries are connected through foreign production by multinational firms. Equilibrium in the world market for manufacturers leads to a system of equations, which allows us to solve for changes in wages and prices from an exogenous change in FDI costs. The computation is based on the approach by Dekle et al. (2008).

We conclude this section by discussing some limitations in our framework. Although regional integration may reduce both trade and investment costs in integrating regions, both parent firm and foreign affiliate are not allowed to export. If export is complementary with FDI for the parent firm in serving foreign markets, we may underestimate the positive impact on FDI because regional integration should promote both export and FDI. If export is a substitute for FDI, the effect on FDI would depend on the extent to which regional integration reduces trade and investment costs. Additionally, a decline in internal trade costs encourages export-platform FDI in integrating market from non-integrating regions. If foreign production is used to export to integrating markets, our model may lead to an underestimated impact on FDI in integrating markets. Finally, these trade impacts may also differ by individual multinational firms because the rules of origin in regional trade agreements produces fixed costs in documentation for each firm to exploit tariff reductions. Such fixed costs 
may discourage smaller multinationals more strongly from utilizing the FTA scheme. Taken together, there remain complex linkages through which falling trade costs affect FDI decisions by heterogeneous multinational firms.

\section{Setup of Policy Experiments}

We design a variety of policy experiments to assess the impact of regional investment liberalization on FDI. Our sample consists of 43 economies, including the rest of the world. To distinguish regional integration, we classify the sample economies as North or South according to the World Bank Income Classification. ${ }^{4}$ There are 22 North economies including Japan, and 21 South economies. In this study, Japan is a headquarters country for simulated multinational firms. The sample allows us to examine different combinations of economies in regional integration: for instance, North-North, North-South, and South-South. The distinction between North and South is crucial for our simulation because outward FDI from North is significantly larger than that from South, implying that a regional decline in investment costs may generate varying effects quantitatively across integrating regions. For instance, outward FDI from North to South is much larger that outward FDI from South to South. Japanese firms may face more intensive competition in South-South integration with North than without North because outward FDI from North to South may drive out Japanese FDI from South. By contrast, the participation of South in North-North integration may have a small influence on Japanese FDI in North because of the relatively low level of outward FDI from South to North.

We consider experiments in which a headquarters country participates in regional

\footnotetext{
${ }^{4}$ The sample economies are listed in Appendix B.
} 
integration and does not participate. Specifically, Japan is the headquarters country for our firm-level dataset on Japanese multinational firms; we simulate a baseline dataset to reproduce their multinational activity. Japan's participation in economic integration should have a substantial implication for FDI decisions by Japanese multinational firms. When Japan participates in regional integration with other economies, Japanese firms would benefit from a lower barrier to offshore production within the integrating economies. In contrast, when Japan does not participate in the regional integration that occurs between other economies, Japanese multinationals would not enjoy a lower investment barrier, but face increased competition in the integrating economies because of an increase in intra-regional FDI activity. In this scenario, a decline in outward FDI should decrease profits earned by Japanese multinationals in foreign markets, which discourage foreign production by Japanese firms. Thus, the participation or non-participation of a headquarters country in regional integration could lead to strikingly different outcomes for Japanese firms engaging in foreign production.

With our sample economies in North and South, Policy 1 is the case in which Japan is integrated with North and South economies. In this experiment, bilateral FDI barriers are reduced uniformly among all the integrating economies. In Policy 2, Japan is integrated with North, but not with South. By contrast, Policy 3 is defined such that Japan integrates with South, but the North economies do not participate in this integration. Furthermore, we also design three policy experiments without Japan's participation in regional integration. In Policy 4, Japan does not integrate with either North or South. In Policy 5, only the North economies are integrated, but Japan and South do not participate in this integration. Finally, Policy 6 is that only the South economies are integrated, but Japan and North do not participate. 
These policy experiments assume that participating economies agree to a bilateral reduction in both fixed and variable costs of offshore production by multinationals among integrating markets. To extend the analysis, we consider the policy experiments in which either fixed or variable costs are reduced. These experiments are motivated by the fact that the scope of investment liberalization in regional integration is not uniform across recent RTAs. As seen in the recent integration processes in ASEAN, investment agreement at an early stage of integration may focus on the protection of foreign investors from government's expropriation and gradually shift to the elimination of foreign-ownership restrictions. In other words, the focus has shifted from ex post investment barriers to ex ante investment restraints. Although it is challenging to estimate the impact of these policies on actual investment costs, an improvement in investment protection should mitigate uncertainty in foreign markets and reduce an efficiency loss of local production for foreign firms. For instance, the North American Free Trade Agreement (NAFTA) grants a settlement mechanism for investor disputes against a foreign government, such as those arising from labor or environmental regulations. American multinationals have filed over twenty claims under this scheme (Akhtar and Weiss, 2013). Thus, investment protection is associated with a reduction in variable costs of local production after an entry to a foreign market. On the other hand, foreign-ownership restrictions raise an entry barrier for foreign investors. For instance, the requirement of a joint venture with local business partners may increase entry costs for foreign firms in searching and negotiating with appropriate local partners. Eliminating ownership restrictions is associated with a decline in fixed costs to establish a foreign plant.

From Policy 1 through Policy 6, we assume a bilateral reduction in both fixed and 
variable costs by $20 \% .^{5}$ In order to examine the differences in FDI barriers, we assume a bilateral decline in either fixed or variable costs by $20 \%$ for the rest of the policy experiments with the participation of Japan in regional integration. This extension gives us additional six policy experiments. We conduct 12 policy experiments in Table 1.

Finally, we provide an intuitive summary of counterfactual simulation procedures. For each experiment, we first compute a bilateral decline in FDI costs across home and host economies. Given an exogenous decrease in the FDI costs, we jointly solve for changes in aggregate wages and prices in each economy. Falling FDI costs induce multinational firms to expand their foreign production, thereby increasing a share of production by foreign firms with high technology in some host economies. Consequently, these economies experience a decline in price levels through better access to cheaper goods because more efficient foreign firms produce at lower marginal costs. Also, additional profits generated from multinational activity flow back into their headquarters economies as additional income is used to consume domestically produced goods. These forces may combine to increase real wages in some host economies. Following the general equilibrium changes in wages and prices, we compute aggregate changes in the entry number and foreign sales of Japanese firms to other economies. Given the counterfactual changes in aggregate entry and sales, we simulate a set of artificial firms on the basis of entry and sales conditions for firm-level behaviors and

\footnotetext{
${ }^{5}$ Because a larger (smaller) decline in investment costs leads to a larger (smaller) impact on multinational activity in our analysis, we place less emphasis on the absolute magnitude of the impact of regional integration.
} 
construct counterfactual data on firm-level entry and sales across productivity groups and foreign markets. Because the model is calibrated to match Japanese multinational activity, the simulated firms should follow closely the response of artificial multinational firms headquartered in Japan to a regional reduction in investment costs.

\section{Counterfactual Results}

\subsection{Aggregate Effects on Multinational Activity}

We start to examine the aggregate impact of regional integration on multinational activity. Table 2 provides a summary of baseline and counterfactual datasets on the aggregate entry and production of Japanese firms in North and South economies. In the baseline, there are on average 101 and 150 Japanese firms investing in North and South, respectively. ${ }^{6}$ Note that the average entry in South decreases down to 85 when we exclude an observation of the largest entry in China. Foreign production by Japanese firms in North and South is on average 2.7 and 1.8 trillion Yen, respectively. Consistent with the empirical observations on multinational activity, the baseline data show the larger offshore production by Japanese firms in North than in South (Barba Navaretti and Venables, 2004). Based on the baseline dataset, we simulate counterfactual changes in aggregate multinational activity across policy experiments.

---Table 2---

In Policy 1, regional integration with both North and South economies increases both entry and foreign production of Japanese firms in these economies. The entry

\footnotetext{
${ }^{6}$ See Appendix A for the baseline dataset used in simulation.
} 
increases by $76.4 \%$ in North and by $72.1 \%$ in South, whereas the production increases by $109.8 \%$ in North and by $76.5 \%$ in South. In Policy 2 , regional integration between Japan and North promotes largely the entry and foreign production of Japanese firms in North. On the other hand, Japan-South integration in Policy 3 encourages significantly the entry and foreign production in South. These results indicate that regional integration generates the effects of investment creation within integrating member economies, consistent with the findings on investment creation effects of regional trade agreements in Baldwin et al. (1999).

Based on these results, we examine whether investment diversion occurs. ${ }^{7}$ By analogy with trade diversion effects of RTAs, investment diversion is associated with production shifting from non-member economies of regional investment liberalization to member economies. Such an effect may be observed when we exclude South from Japan-North integration in Policy 2 or North from Japan-South integration in Policy 3. In Policy 2, we find that Japanese multinational activity decreases on average in non-integrating South economies. Because multinational activity increases in integrating North economies, the result can be interpreted as suggesting that Japanese multinational firms shift foreign production away from non-member to member economies of the investment agreement, consistent with an investment diversion effect. Nevertheless, we should highlight that the erosion effect on multinational activity in South is not quantitatively large relative to the creation effect in North. Additionally, the result in Policy 3 shows that Japanese multinational activity does not appear to decline in non-integrating North economies substantially, implying the absence of investment diversion. In our general equilibrium framework, production shifting through FDI

\footnotetext{
${ }^{7}$ We thank a reviewer for suggesting this issue.
} 
activity may occur because FDI activity in non-integrating economies is partly related to a change in production costs in other integrating economies. Despite the theoretical setup, we find that the diversion effect would be quantitatively small in our policy experiments even with a relatively large decline in regional investment costs. Thus, evidence of investment diversion is weak.

We turn to discuss the results when Japan does not participate in regional integration of other economies for Policies 4 to 6 . Across these experiments, the entry of Japanese firms to North and South decreases for intensified competition in foreign markets resulting from increased FDI activity among integrating economies. Foreign production of Japanese firms also declines in South. However, we find an increase in foreign production in North for Policies 4 and 5. In terms of a general equilibrium framework, North-North integration promotes intra-regional FDI activity substantially and could generate strong income effects through increased profits remitted from abroad by their multinational firms. Because repatriated profits are spent on production at home, such effects would increase demand for foreign production of incumbent multinationals in North from a non-integrating economy, that is, Japan. Despite the negative impact of intensified competition, the strong income effects could induce the incumbent Japanese multinationals to increase their foreign production in North. By contrast, South-South integration is not likely to encourage intra-regional FDI activity strongly, thereby generating only weak income effects. In this case, increased competition should lead to a dominant negative impact on foreign production of Japanese firms in South.

Comparing the results between Policy 4 and Policy 6, we find that foreign production of Japanese firms in South economies decrease more substantially in Policy 4 than in Policy 6. The reason is that the participation of North economies in 
South-South integration should increase largely multinational activity in South from North, implying a stronger competition effect in South for Japanese multinational firms. By contrast, the non-participation of North implies a more moderate increase in multinational activity among South economies. Therefore, South-South integration leads to a smaller contraction of Japanese multinational activity.

\subsection{Firm-level Effects on Multinational Activity}

We turn to discuss firm-level impacts on multinational activity. Table 3 shows a baseline dataset on simulated firms, which are generated from a new set of productivity draw and entry/sales shocks specific to each firm and the structural parameters estimated from the data on Japanese multinational firms for $2006 .{ }^{8}$ We aggregate the simulated firms according to productivity percentiles and classify those penetrating a foreign market as multinational firms. In total, there are 1,734 multinationals. While no multinational firm belongs to the bottom $10 \%$ group, 937 multinationals exist in the top $10 \%$ group. As all the firms in the top $1 \%$ invest abroad, the top $10 \%$ group accounts for $54 \%$ of multinational firms. Consistent with the heterogeneous firm literature, the number of multinational firms increases with firm-level productivity. More productive firms are more likely than less productive firms to generate larger production in both domestic and foreign markets. The distribution of foreign production is highly skewed. These features highlight the crucial role of firm heterogeneity in analyzing the impact of regional investment liberalization.

---Table 3---

\footnotetext{
${ }^{8}$ See Appendix A for the data source.
} 
Given an exogenous decline in FDI barriers, we simulate a set of artificial firms based on counterfactual changes in aggregate foreign entry and sales of Japanese firms. In Table 4, we present counterfactual percentage changes from the baseline at the extensive margin of multinational activity across productivity levels, where the extensive margin is an establishment of foreign production for each firm group. In Policy 1, we find the varying impacts at the extensive margin across productivity levels. There is no change for the top $1 \%$ firms because all the firms in this group have already invested abroad. By contrast, there are larger percentage increases at the extensive margin for less productive firms. Although the baseline number of multinationals is smaller in the lower productivity group, North-South integration with Japan encourages the growth of less productive firms at the extensive margin more strongly.

In Policies 2 and 3, there are also larger percentage increases at the extensive margin for less productive firms, consistent with the result in Policy 1. While aggregate effects of investment creation are found in the literature, we further demonstrate that such creation effects differ by individual firms significantly. Additionally, comparing the results in Policies 2 and 3, we find that Japan-South integration increases the extensive-margin growth more significantly than Japan-North integration does, suggesting that creation effects on the extensive-margin growth are magnified in regional integration with South than with North. In particular, large positive impacts for less productive firms in Policy 3 suggest that regional integration with South is expected to attract a larger number of new foreign investors that are less productive than incumbent foreign investors in South markets. These results are likely to be mainly due to the different level of competition between North and South markets. In Policy 2 , 
regional integration with North induces foreign investors from North to increase their foreign production largely and strengthen competition effects for Japanese multinationals in North markets. In Policy 3, Japanese multinationals would face less competition in South markets because regional integration with South would not strongly encourage foreign production by firms headquartered in South. Such a difference between North and South may generate a quantitatively large impact on less productive firms more strongly in terms of the extensive-margin growth.

---Table 4---

In Policy 4, North-South integration without the participation of Japan leads to varying negative impacts at the extensive margin across productivity levels. While there is no negative impact on the top $1 \%$ firms, there are larger negative impacts on less productive firms. Despite the increased competition in foreign markets from regional integration, the most productive firms do not suffer from such impacts largely. By contrast, the intensified competition drives out strongly a group of less productive firms that barely overcome entry hurdles abroad prior to regional integration. These negative impacts on the extensive-margin growth are also observed in North-North and South-South integrations without Japan for Policies 5 and 6, respectively. Therefore, our analysis demonstrates that the exclusion of a headquarters country from regional integration could generate the investment discouragement effects that differ across firm-level efficiency in terms of the extensive-margin growth.

We proceed to discuss the average size of foreign production at the firm-level, i.e., the intensive margin of multinational production. In Table 5, we show counterfactual 
percentage changes from the baseline at the intensive margin across productivity levels. In Policy 1, the average volume of foreign production in each productivity group increases and such positive effects on the intensive margin are more pronounced for less productive firms. Policies 2 and 3 show that the intensive-margin growth is generally positive across productivity levels whereas it tends to be larger for less productive firms. Comparing Japan-North and Japan-South integrations, the former experiment generates a larger positive impact on the intensive-margin growth in part because the market size is larger in North economies. It should be highlighted that firm-level effects at the intensive margin are less clear-cut than those at the extensive margin because regional integration promotes both entry and foreign production. Despite an increase in aggregate foreign production, a more pronounced increase in the entry could dampen the intensive-margin growth for some productivity groups. Finally, we emphasize that the average production volume is remarkably larger for most productive firms, implying that the positive impact on the volume of their foreign production is substantially large in magnitude.

---Table 5---

For Policies 4 to 6, we find that regional integration among other economies does not necessarily decrease the average volume of foreign production by Japanese firms. By contrast with the extensive margin, firm-level effects are not clear-cut across productivity levels because an exit of incumbent multinationals and shrinking foreign production combine to determine the intensive margin in each productivity group. However, we find that the intensive-margin growth is positive for the top $1 \%$ firms 
across these experiments. In particular, North-North integration increases their intensive-margin growth more significantly than South-South integration does. The reason is that the most productive firms are not driven out by intensified competition in foreign markets, but benefit from income effects among integrating economies resulting from an increase in intra-regional FDI activity. Consequently, the regional integration among other economies could induce the most productive firms to expand their foreign production in terms of the intensive-margin growth. The income effects may have a greater impact on the most productive firms in North-North integration than in South-South integration.

\subsection{The Impacts of Fixed and Variable FDI Costs on Multinational Activity}

We proceed to examine whether the type of regional investment agreement affects multinational activity differently. Specifically, we examine whether fixed and variable costs of foreign production play a varying role in policy experiments. Focusing on regional integration with the participation of Japan, we conduct a series of policy experiments in which either fixed or variable costs are reduced for North-South, North-North, and South-South integrations.

Table 6 provides a summary of baseline and counterfactual datasets on the aggregate entry and production of Japanese firms for Policies 7 to 12 . Consistent with the result of Policy 1, Policies 7 and 8 show an increase in both entry and production of Japanese firms in North and South economies. Comparing these experiments, we find similar counterfactual changes in the entry, but different impacts on the volume of production. For instance, a reduction in fixed and variable costs increases the average foreign production in North by $21.9 \%$ and by $67.7 \%$, respectively. On the other hand, the 
average foreign production in South increases by $12.8 \%$ and $45.9 \%$, respectively. Therefore, falling variable costs generate a substantially large positive impact on multinational production, and such positive impact is more pronounced in North economies.

We find that variable costs tend to produce larger impacts on foreign production than fixed costs for Policies 9 to 12. In North-North integration, the average foreign production in North increases by $20.9 \%$ for Policy 9 and by $64.6 \%$ for Policy 10 , respectively. In South-South integration, the average volume of foreign production in South increases by $12.6 \%$ for Policy 11 and by $44.9 \%$ for Policy 12 . Additionally, we find that a reduction in fixed costs has a greater impact on entry in South economies. While a reduction in fixed costs is expected to have a greater impact on entry than a reduction in variable costs, we find the quantitatively larger impact on entry in South for Policy 12 than for Policy 11. Because the entry condition depends on both fixed and variable costs, our analysis shows that falling variable costs in South economies could be more influential in attracting new foreign investors.

---Table 6---

Taken together, we find that a reduction in fixed and variable costs of foreign production produces positive impacts on multinational entry and production while the variable costs tend to have a pronounced impact. These results yield an implication for an impact of RTAs. If a regional investment agreement is associated primarily with foreign-ownership restrictions and other entry regulations, we expect that regional integration should promote FDI activity in integrating economies. When it is associated 
mainly with an improvement in business environments and protection for foreign investors, we expect that regional integration should yield a larger impact on foreign production by incumbent multinational firms. Additionally, the impact on multinational production may be greater in integration with North than with South in part because of the larger market size in North. On the other hand, the impact on multinational entry may be larger in integration with South than with North in part because foreign investors from South have a weaker competition effect. Overall, different policy instruments entail different implications for potential impacts of the regional investment agreement on multinational production. The impacts also depend quantitatively on which countries participate in the regional agreement.

\section{Conclusion}

With the proliferation of regional economic integration, and an investment agreement has been widely negotiated among participating members to improve the protection of foreign investors and reduce a discriminatory entry barrier. This study conducts policy experiments to investigate a relationship between regional investment liberalization and FDI activity. Our counterfactual analysis is based on the calibrated model of firm heterogeneity to match data on Japanese multinational firms. We find evidence of investment creation effects from a regional decline in investment costs. Also, multinational firms with heterogeneous productivity respond differently to regional integration in terms of the extensive- and intensive-margin growth. For instance, the creation effects could be larger for less productive firms in terms of the extensive-margin growth, but the exclusion of a headquarters country from regional integration may produce a pronounced negative impact on these firms. 
Our analysis provides policy implications for RTAs. Provisions for direct investment in RTAs can indeed promote FDI activity among participating economies. The positive impact on multinational activity increases with the number of participating economies, suggesting a greater benefit from wide regional RTAs. Additionally, the non-participation into RTAs among other economies may discourage foreign production by multinational firms headquartered in non-participating economies. Such a negative impact is more pronounced for less productive firms investing abroad. Despite increased competition abroad, the most productive multinational firms may expand their foreign production for strong income effects from regional integration. Thus, RTAs produce heterogeneous impacts across individual firms in both participating and non-participating economies.

Finally, there are remaining issues for future research. It is of great interest to analyze the impact of specific types of RTAs from a policy perspective. A challenge for such a quantitative assessment is the lack of a reliable dataset to measure the impact of specific RTAs on variable and fixed costs of FDI activity. A reliable estimate of such relationships is crucial for investigating the plausible magnitude of the impact of RTAs. Moreover, it is promising to investigate how a reduction in both trade and investment barriers affects multinational production at the firm-level. 


\section{Acknowledgements}

This study is conducted as a part of the project "Economic Analysis on Trade Agreements" undertaken at the Research Institute of Economy, Trade and Industry (RIETI). We acknowledge the financial support of JSPS Grant-in-Aid for Scientific Research (B) Grant Number 26285058 and Young Scientists (B) Grant Number 24730232. The authors would like to thank RIETI for research opportunities. For their useful comments, we thank Hitoshi Sato, Hikari Ishido, Tadashi Ito, Isao Kamata, Yoshimasa Komoriya, Hiroshi Mukunoki, and seminar participants at Tohoku University. The opinions expressed and arguments employed in this paper are the sole responsibility of the authors and do not necessarily reflect those of RIETI, METI, or any institution with which the authors are affiliated. All remaining errors are our own.

\section{References}

Akhtar, S. I. \& Weiss, M. A. (2013). U.S. international investment agreements: issues for Congress. Congressional Research Service: 7-5700.

Altomonte, C. (2007). Regional economic integration and the location of multinational firms. Review of World Economics, 143(2), 277-305.

Arita, S., \& Tanaka, K. (2014). Heterogeneous multinational firms and productivity gains from falling FDI barriers. Review of World Economics, 150(1),: 83-113.

Baldwin, R. E., Forslid, R., \& Haaland, J. I. (1999). Investment creation and investment diversion: simulation analysis of the single market programme. Dynamic Issues in Commercial Policy Analysis, 228-65.

Baltagi, B. H., Egger, P., \& Pfaffermayr, M. (2008). Estimating regional trade agreement effects on FDI in an interdependent world. Journal of Econometrics, 145(1), 194-208.

Barba Navaretti, G., Venables, A.J., 2004. Multinational Firms in the World Economy. Princeton: Princeton University Press.

Barrell, R., \& Pain, N. (1999). Domestic institutions, agglomerations and foreign direct investment in Europe. European Economic Review, 43(4), 925-934.

Chen, M. X. (2009). Regional economic integration and geographic concentration of multinational firms. European Economic Review, 53(3), 355-375.

Chen, M. X. \& Moore, M. O. (2010). Location decision of heterogeneous multinational firms. Journal of International Economics, 80(2), 188-199.

Dekle, R., Eaton, J., Kortum, S. (2008). Global rebalancing with gravity: measuring the burden of adjustment. IMF Staff Papers 55(3), 511-540.

Eaton, J., Kortum, S., \& Kramarz, F. (2011). An anatomy of international trade: evidence from French firms. Econometrica, 79(5), 1453-1498.

Egger, P., Larch, M., \& Pfaffermayr, M. (2007). On the welfare effects of trade and investment liberalization. European Economic Review, 51(3), 669-694. 
Ekholm, K., Forslid, R., \& Markusen, J. R. (2007). Export-platform foreign direct investment. Journal of the European Economic Association, 5(4), 776-795.

Grossman, G. M., Helpman, E., \& Szeidl, A. (2006). Optimal integration strategies for the multinational firm. Journal of International Economics, 70(1), 216-238.

Irarrazabal, A., Moxnes, A., \& Opromolla, L. D. (2013). The margins of multinational production and the role of intrafirm trade. Journal of Political Economy, 121(1), 74-126.

Kim, Y. H. (2007). Impacts of regional economic integration on industrial relocation through FDI in East Asia. Journal of Policy Modeling, 29(1), 165-180.

Kitwiwattanachai, A., Nelson, D., \& Reed, G. (2010). Quantitative impacts of alternative East Asia Free Trade Areas: a computable general equilibrium (CGE) assessment. Journal of Policy Modeling, 32(2), 286-301.

MacDermott, R. (2007). Regional trade agreement and foreign direct investment. The North American Journal of Economics and Finance, 18(1), 107-116.

Markusen, J. R. (2002). Multinational firms and the theory of international trade. Cambridge, MA: MIT Press.

Montout, S., \& Zitouna, H. (2005). Does North-South integration affect multinational firms' strategies? Review of International Economics, 13(3), 485-500.

Motta, M., \& Norman, G. (1996). Does economic integration cause foreign direct investment? International Economic Review, 37(4), 757-783.

Park, I., \& Park, S. (2007). Reform creating regional trade agreements and foreign direct investment: applications for East Asia. Pacific Economic Review, 13(5), 550-566.

Ranjan, P. (2006). Preferential trade areas, multinational enterprises, and welfare. Canadian Journal of Economics, 39(2), 493-515.

Tekin-Koru, A., \& Waldkirch, A. (2010). North-South integration and the location of foreign direct investment. Review of International Economics, 18(4), 696-713.

Tintelnot, F. (2012). Global production with export platforms. Mimeo, Penn State University.

Yeaple, S. R. (2003). The complex integration strategies of multinationals and cross country dependencies in the structure of foreign direct investment. Journal of International Economics, 60(2), 293-314.

Yeaple, S. R. (2009). Firm heterogeneity and the structure of U.S. multinational activity: an empirical analysis. Journal of International Economics, 78(2), 206-215. 


\section{Appendix A}

This appendix summarizes the details of our methodological framework to conduct a counterfactual analysis of heterogeneous multinational firms in a general equilibrium model. Further details of the methodology are found in Arita and Tanaka (2014).

\section{A1. Calibration}

To calibrate the model, the entry and sales conditions are re-specified. To isolate the heterogeneous component of unit costs, we define standardized unit costs as follows:

$$
u(j)=T_{i} z_{i}(j)^{-\theta} \text {. }
$$

By connecting the country-level parameters in equation (8) with the total number of firm entries $N_{n i}$, we express the entry hurdle as follows:

$$
u(j) \leq \bar{u}_{n i}\left(\eta_{n}(j)\right)=N_{n i} \kappa_{2}{ }^{-1} \eta_{n}(j)^{\widetilde{\theta}},
$$

where $\tilde{\theta}=\theta /(\sigma-1)>1$ and $\kappa_{2}=\int \eta^{\widetilde{\theta}} g_{2}(\eta) d \eta . \bar{u}_{n i}(\cdot)$ is a standardized entry hurdle in market $n$ for potential producer $j$ in country $i$. $\tilde{\theta}$ is the heterogeneity in observed sales, with a lower value indicating a larger dispersion in sales across firms. Conditional on entry, the sales condition for firm $j$ in market $n$ is rewritten as

$$
X_{n i}(j)=\frac{\alpha_{n}(j)}{\eta_{n}(j)} \overline{\mathrm{X}}_{n i} \frac{\kappa_{2}}{\kappa_{1}}\left(v_{n i}(j)\right)^{-1 / \widetilde{\theta}},
$$

where $\overline{\mathrm{X}}_{n i}$ is the average sales in market $n$ of foreign affiliates by multinationals from country $i, \kappa_{0}=\tilde{\theta} /(\tilde{\theta}-1)$, and $\kappa_{1}=\kappa_{0} \iint \alpha_{n}(j) \eta_{n}(j)^{(\widetilde{\theta}-1)} g(\alpha, \eta) d \alpha d$. We assume that the parameter $v_{n i}(j)=u(j) / \bar{u}_{n i}\left(\eta_{n}(j)\right)$ follows a uniform distribution on $[0,1]$.

To parameterize $\kappa_{1}$ and $\kappa_{2}, g(\alpha, \eta)$ is assumed to be joint lognormal with zero means, variances $\left(\sigma_{\alpha}\right.$ and $\left.\sigma_{\eta}\right)$, and correlation $\rho$. Thus, we can express $\kappa_{1}$ and $\kappa_{2}$ as follows:

$$
\begin{aligned}
\kappa_{1} & =\left[\frac{\widetilde{\theta}}{\widetilde{\theta}-1}\right] \exp \left[\frac{\sigma_{\alpha}+2 \rho \sigma_{\alpha} \sigma_{\eta}(\widetilde{\theta}-1)+\sigma_{\eta}(\widetilde{\theta}-1)^{2}}{2}\right], \\
\kappa_{2} & =\exp \left[\frac{\left(\widetilde{\theta} \sigma_{\eta}\right)^{2}}{2}\right] .
\end{aligned}
$$

Taken together, the entry and sales conditions are governed by four structural parameters: heterogeneity in observed sales $\tilde{\theta}$, variance in sales $\sigma_{\alpha}$, variance in entry shocks $\sigma_{\eta}$, and their correlation $\rho$. We denote the set of these structural parameters as

$$
\Theta=\left(\tilde{\theta}, \sigma_{\alpha}, \sigma_{\eta}, \rho\right)
$$

We estimate a set of optimal structural parameters by calibrating the model to match firm-level data in Japan. Specifically, we use microdata pertaining to the Basic Survey of Japanese Business Structure and Activities conducted by the Japanese Ministry of Economy, Trade, and Industry (METI), which covers all business firms with 50 
employees or more and capital of 30 million yen or more. To link foreign affiliate sales with Japanese parent firms, we use microdata pertaining to the Survey of Overseas Business Activities conducted by METI, which covers the multinational parent firms that are headquartered in Japan and own at least one foreign business enterprise. For calibration, we primarily use the sample on manufacturing multinational firms in 2006, which consists of 2,032 parent firms with 7,626 foreign affiliates. However, the figures for domestic sales are missing for some parent firms, making it difficult to measure a linkage between domestic and foreign sales for them. After excluding these firms, we have 1,656 parent firms in the sample.

We employ the simulated method of moments for estimation. In the first step, we use the entry and sales conditions in equations (A2) and (A3) to simulate an artificial producer $s$ by generating its efficiency draw $u(s)$, sales shock $\alpha_{n}(s)$, and entry shock $\eta_{n}(s)$. With an initial guess for the structural parameters and aggregate data on Japanese multinationals, we produce a dataset of hypothetical firms, including the market entry and affiliate sales across markets. Second, we construct a set of moment conditions from simulated multinationals and actual Japanese multinationals. We define a vector of deviations between actual and hypothetical moments for outcome $k$ :

$$
y(\Theta)=m^{k}-\widehat{m}^{k}(\Theta) .
$$

Following the theoretical implications, we choose four moment conditions: pecking order strings, affiliate sales distributions across markets, parent sales distribution in Japan, and multinational production intensity. Stacking a vector of moment conditions, we minimize the objective function with respect to the structural parameters as follows:

$$
\widehat{\Theta}=\arg \min _{\Theta}\left\{\left[m^{k}-\widehat{m}^{k}(\Theta)\right]^{\prime}\left[m^{k}-\widehat{m}^{k}(\Theta)\right]\right\} .
$$

To mitigate the influence of noisier segments of the data, we exclude markets with less than 10 foreign affiliates from the estimation. The best fit is obtained for the following structural parameters with bootstrapped standard errors in parenthesis:

\begin{tabular}{cccc}
\hline$\tilde{\theta}$ & $\sigma_{a}$ & $\sigma_{\eta}$ & $\rho$ \\
\hline \hline 1.99 & 1.64 & 0.39 & -0.62 \\
$(0.43)$ & $(0.07)$ & $(0.31)$ & $(0.34)$ \\
\hline
\end{tabular}

The parameters are quite similar in magnitude to the corresponding estimates for French exporters in EKK (2011). Additionally, we check the robustness of the benchmark estimates by estimating the parameters alternatively for all the markets, without the pecking order of entry from the moment conditions, and the data in 1996. These checks demonstrate the robustness of the benchmark estimates to the sample and moments. 


\section{A2. General Equilibrium}

Each country is endowed with labor, which is mobile within countries, but immobile across countries. Intermediates are a Cobb-Douglas combination of labor and intermediates. Final output is non-traded and a Cobb-Douglas combination of manufactured goods and labor. Fixed cost for FDI is paid by labor. Profits accrue to the headquarters countries of producers. As consumers own equal shares of each firm headquartered in their country, the profits are redistributed equally among the consumers. A country's GDP is equal to its total wage from production in its own country and its total profit from abroad. Lastly, some countries are net receivers for FDI, implying that they incur FDI deficits.

Solving for prices and wages jointly, we calculate counterfactual changes in the entry and affiliate sales of Japanese firms across markets, $\widehat{X}_{n J}^{C}$ and $\widehat{N}_{n J}^{C}$. Given these counterfactual changes, we use the entry and sales conditions in equations (A2) and (A3) to specify the corresponding counterfactual conditions for firm-level behaviors as follows:

$$
\begin{aligned}
& u(s) \leq \bar{u}_{n J}^{C}\left(\eta_{n}(s)\right)=N_{n J}^{C} \kappa_{2}{ }^{-1} \eta_{n}(s)^{\widetilde{\theta}}, \\
& X_{n J}^{C}(s)=\bar{X}_{n J}^{C}(s) \frac{\alpha_{n}(j)}{\eta_{n}(j)} \frac{\kappa_{2}}{\kappa_{1}}\left(\frac{u(s)}{\bar{u}_{n}^{C}(s)}\right)^{-1} / \widetilde{\theta}
\end{aligned}
$$

Holding the structural parameters fixed, we next simulate a set of artificial firms on the basis of equations (A8) and (A9). Throughout the counterfactuals, we fix productivity draws and entry/sales shocks specific to each firm. Thus, all changes in firm-level activity relative to the baseline stem solely from a change in aggregate FDI barriers. 
Table 1. A Summary of Policy Experiments for Regional Integration

\begin{tabular}{|c|c|c|c|c|c|}
\hline \multirow{2}{*}{ Policy No. } & \multirow{2}{*}{$\begin{array}{c}\text { Japan's } \\
\text { Participation }\end{array}$} & \multicolumn{2}{|c|}{$\underline{\text { Integrating Members }}$} & \multicolumn{2}{|c|}{$\underline{\text { Change in Bilateral FDI Costs }}$} \\
\hline & & North & South & Fixed Cost & Variable Cost \\
\hline Policy 1 & Yes & Yes & Yes & $20 \%$ decline & $20 \%$ decline \\
\hline Policy 2 & Yes & Yes & No & $20 \%$ decline & $20 \%$ decline \\
\hline Policy 3 & Yes & No & Yes & $20 \%$ decline & $20 \%$ decline \\
\hline Policy 4 & No & Yes & Yes & $20 \%$ decline & $20 \%$ decline \\
\hline Policy 5 & No & Yes & No & $20 \%$ decline & $20 \%$ decline \\
\hline Policy 6 & No & No & Yes & $20 \%$ decline & $20 \%$ decline \\
\hline Policy 7 & Yes & Yes & Yes & $20 \%$ decline & Constant \\
\hline Policy 8 & Yes & Yes & Yes & Constant & $20 \%$ decline \\
\hline Policy 9 & Yes & Yes & No & $20 \%$ decline & Constant \\
\hline Policy 10 & Yes & Yes & No & Constant & $20 \%$ decline \\
\hline Policy 11 & Yes & No & Yes & $20 \%$ decline & Constant \\
\hline Policy 12 & Yes & No & Yes & Constant & $20 \%$ decline \\
\hline
\end{tabular}


Table 2. Aggregate Impacts on Foreign Production by Japanese Firms

\begin{tabular}{|c|c|c|c|c|c|c|c|}
\hline & \multirow{2}{*}{ Baseline } & \multicolumn{6}{|c|}{ Counterfactual Data } \\
\hline & & Policy 1 & Policy 2 & Policy 3 & Policy 4 & Policy 5 & Policy 6 \\
\hline \multicolumn{8}{|c|}{ Panel A: Entry in North } \\
\hline \multirow[t]{2}{*}{ Mean } & 101.0 & 178.2 & 184.9 & 100.8 & 83.0 & 85.7 & 100.0 \\
\hline & & $(76.4)$ & $(83.1)$ & $(-0.2)$ & $(-17.8)$ & $(-15.1)$ & $(-1.0)$ \\
\hline Std. Dev. & 149.8 & 296.8 & 303.0 & 153.0 & 138.1 & 140.7 & 152.4 \\
\hline \multicolumn{8}{|c|}{ Panel B: Production in North } \\
\hline \multirow[t]{2}{*}{ Mean } & 2.75 & 5.76 & 5.63 & 2.77 & 2.85 & 2.96 & 2.68 \\
\hline & & $(109.8)$ & $(105.2)$ & $(0.9)$ & $(3.8)$ & $(7.8)$ & $(-2.4)$ \\
\hline Std. Dev. & 6.02 & 12.44 & 12.33 & 6.18 & 6.30 & 6.45 & 6.11 \\
\hline \multicolumn{8}{|c|}{ Panel C: Entry in South } \\
\hline \multirow[t]{2}{*}{ Mean } & 150.0 & 258.2 & 146.2 & 302.8 & 125.7 & 146.4 & 146.1 \\
\hline & & $(72.1)$ & $(-2.6)$ & $(101.8)$ & $(-16.2)$ & $(-2.4)$ & $(-2.6)$ \\
\hline Std. Dev. & 318.4 & 544.9 & 315.9 & 671.3 & 260.6 & 316.8 & 315.9 \\
\hline \multicolumn{8}{|c|}{ Panel D: Production in South } \\
\hline \multirow[t]{2}{*}{ Mean } & 1.80 & 3.18 & 1.68 & 3.13 & 1.43 & 1.69 & 1.71 \\
\hline & & $(76.5)$ & $(-6.6)$ & $(74.1)$ & $(-20.6)$ & $(-6.2)$ & $(-5.1)$ \\
\hline Std. Dev. & 3.53 & 6.27 & 3.32 & 6.16 & 2.81 & 3.34 & 3.37 \\
\hline
\end{tabular}

Notes: Figures in parenthesis indicate the percentage changes in counterfactual data from the baseline; production is measured in trillions of Yen. 
Table 3. Baseline Dataset at the Firm Level

\begin{tabular}{|c|c|c|c|c|c|c|}
\hline $\begin{array}{l}\text { Initial Productivity } \\
\text { Group (percentile) }\end{array}$ & $\begin{array}{c}\text { Number of } \\
\text { Domestic Firms }\end{array}$ & $\begin{array}{c}\text { Number of } \\
\text { Multinationals }\end{array}$ & $\begin{array}{l}\text { Number of } \\
\text { All Firms }\end{array}$ & $\begin{array}{l}\text { Domestic Production } \\
\text { per Domestic Firm }\end{array}$ & $\begin{array}{l}\text { Foreign Production } \\
\text { per Multinational }\end{array}$ & $\begin{array}{l}\text { Total Production } \\
\text { per Firm }\end{array}$ \\
\hline $0-10$ & 1,318 & 0 & 1,318 & 12.2 & - & 12.2 \\
\hline $10-20$ & 1,307 & 11 & 1,318 & 13.9 & 0.6 & 13.8 \\
\hline $20-30$ & 1,303 & 15 & 1,318 & 15.6 & 0.9 & 15.4 \\
\hline $30-40$ & 1,290 & 28 & 1,318 & 16.6 & 0.7 & 16.3 \\
\hline $40-50$ & 1,284 & 33 & 1,317 & 21.4 & 0.9 & 20.9 \\
\hline $50-60$ & 1,247 & 71 & 1,318 & 24.8 & 1.3 & 23.6 \\
\hline $60-70$ & 1,210 & 107 & 1,317 & 31.6 & 1.7 & 29.2 \\
\hline $70-80$ & 1,146 & 171 & 1,317 & 32.9 & 2.9 & 29.0 \\
\hline $80-90$ & 957 & 360 & 1,317 & 54.7 & 5.7 & 41.3 \\
\hline $90-99$ & 380 & 806 & 1,186 & 275.6 & 38.2 & 114.3 \\
\hline $99-100$ & 0 & 131 & 131 & - & 586.5 & 956.8 \\
\hline All & 11,441 & 1,734 & 13,174 & 36.4 & 63.8 & 40.0 \\
\hline
\end{tabular}

Note: Production is measured in billions of Yen. 
Table 4. Results for Extensive Margin of Multinational Firms

\begin{tabular}{crrrrrr}
\hline Initial Productivity & \multicolumn{7}{c}{ Counterfactual change from baseline (\%) } \\
Group (percentile) & Policy 1 & Policy 2 & Policy 3 & Policy 4 & Policy 5 & Policy 6 \\
\hline $0-10$ &. &. &. &. &. &. \\
$10-20$ & 240.0 & 33.3 & 262.5 & -50.0 & -11.8 & -11.1 \\
$20-30$ & 185.7 & 56.5 & 236.7 & -33.3 & -4.0 & -7.7 \\
$30-40$ & 242.4 & 81.3 & 275.0 & -39.1 & -5.6 & -5.9 \\
$40-50$ & 190.9 & 50.0 & 208.3 & -41.2 & -13.3 & -5.0 \\
$50-60$ & 136.6 & 36.4 & 202.9 & -31.3 & -5.4 & -1.7 \\
$60-70$ & 120.6 & 37.6 & 143.9 & -34.1 & -6.7 & -6.5 \\
$70-80$ & 121.1 & 27.2 & 126.9 & -34.3 & -4.8 & -4.8 \\
$80-90$ & 78.6 & 34.6 & 91.8 & -22.8 & -4.8 & -2.1 \\
$90-99$ & 20.2 & 14.6 & 20.6 & -9.0 & -1.8 & -1.5 \\
$99-100$ & 0.0 & 0.0 & 0.0 & 0.0 & 0.0 & 0.0 \\
\hline All & 61.5 & 23.4 & 71.5 & -18.0 & -3.2 & -2.3 \\
\hline \hline
\end{tabular}


Table 5. Results for Intensive Margin of Multinational Firms

\begin{tabular}{crrrrrr}
\hline Initial Productivity & \multicolumn{7}{c}{ Counterfactual change from baseline (\%) } \\
Group (percentile) & Policy 1 & Policy 2 & Policy 3 & Policy 4 & Policy 5 & Policy 6 \\
\hline $0-10$ &. &. &. &. &. &. \\
$10-20$ & 55.0 & 133.9 & 5.1 & 67.5 & 5.0 & -14.9 \\
$20-30$ & 135.4 & 163.0 & 138.7 & 11.6 & -6.6 & -8.4 \\
$30-40$ & 242.1 & 51.8 & 57.4 & -19.5 & 0.2 & -10.0 \\
$40-50$ & 129.3 & 150.8 & 109.2 & -14.0 & 1.6 & -2.5 \\
$50-60$ & 106.5 & 190.2 & 30.4 & 23.2 & -11.0 & -13.0 \\
$60-70$ & 150.6 & 111.6 & 20.0 & 18.4 & -2.2 & -4.3 \\
$70-80$ & 95.5 & 93.0 & 47.1 & 10.7 & -2.3 & -1.9 \\
$80-90$ & 106.1 & 80.4 & 46.3 & 20.4 & -4.4 & -5.0 \\
$90-99$ & 98.5 & 55.4 & 30.5 & 12.8 & -2.7 & -2.1 \\
$99-100$ & 67.2 & 51.2 & 21.2 & 17.7 & 7.5 & 0.8 \\
\hline All & 19.7 & 28.9 & -20.3 & 38.7 & 6.6 & 1.7 \\
\hline \hline
\end{tabular}


Table 6. Aggregate Impacts of Fixed and Variable Costs on Foreign Production

\begin{tabular}{|c|c|c|c|c|c|c|c|}
\hline & \multirow{2}{*}{ Baseline } & \multicolumn{6}{|c|}{$\underline{\text { Counterfactual Data }}$} \\
\hline & & Policy 7 & Policy 8 & Policy 9 & Policy 10 & Policy 11 & Policy 12 \\
\hline \multicolumn{8}{|c|}{ Panel A: Entry in North } \\
\hline \multirow[t]{2}{*}{ Mean } & 101.0 & 135.3 & 132.7 & 137.0 & 136.4 & 100.2 & 100.7 \\
\hline & & $(34.0)$ & $(31.4)$ & $(35.6)$ & $(35.08)$ & $(-0.8)$ & $(-0.3)$ \\
\hline Std. Dev. & 149.8 & 211.9 & 215.3 & 213.1 & 218.7 & 152.4 & 152.8 \\
\hline \multicolumn{8}{|c|}{ Panel B: Production in North } \\
\hline \multirow[t]{2}{*}{ Mean } & 2.75 & 3.35 & 4.61 & 3.32 & 4.52 & 2.70 & 2.74 \\
\hline & & $(21.9)$ & $(67.7)$ & $(20.9)$ & $(64.6)$ & $(-1.7)$ & $(-0.2)$ \\
\hline Std. Dev. & 6.02 & 7.52 & 10.10 & 7.48 & 10.00 & 6.13 & 6.16 \\
\hline \multicolumn{8}{|c|}{ Panel C: Entry in South } \\
\hline \multirow[t]{2}{*}{ Mean } & 150.0 & 198.5 & 193.6 & 146.4 & 146.3 & 207.0 & 215.6 \\
\hline & & $(32.3)$ & $(29.0)$ & $(-2.4)$ & $(-2.5)$ & $(38.0)$ & $(43.7)$ \\
\hline Std. Dev. & 318.4 & 426.9 & 412.2 & 316.7 & 316.2 & 450.8 & 474.2 \\
\hline \multicolumn{8}{|c|}{ Panel D: Production in South } \\
\hline \multirow[t]{2}{*}{ Mean } & 1.80 & 2.03 & 2.62 & 1.69 & 1.68 & 2.03 & 2.61 \\
\hline & & $(12.8)$ & $(45.9)$ & $(-6.2)$ & $(-6.5)$ & $(12.6)$ & $(44.9)$ \\
\hline Std. Dev. & 3.53 & 4.01 & 5.18 & 3.34 & 3.33 & 4.01 & 5.14 \\
\hline
\end{tabular}

Notes: Figures in parenthesis indicate the percentage changes in counterfactual data from the baseline; production is measured in trillions of Yen. 


\section{Appendix B}

Table B1. A List of Sample Economies

\begin{tabular}{|c|c|c|c|}
\hline \multicolumn{2}{|c|}{$\underline{\text { North }}$} & \multicolumn{2}{|c|}{$\underline{\text { South }}$} \\
\hline Economy & Income & Economy & Income \\
\hline Japan & High income: OECD & Turkey & Upper middle income \\
\hline United States & High income: OECD & Argentina & Upper middle income \\
\hline United Kingdom & High income: OECD & Brazil & Upper middle income \\
\hline Austria & High income: OECD & Chile & Upper middle income \\
\hline Denmark & High income: OECD & Mexico & Upper middle income \\
\hline France & High income: OECD & Peru & Upper middle income \\
\hline Germany & High income: OECD & Malaysia & Upper middle income \\
\hline Italy & High income: OECD & South Africa & Upper middle income \\
\hline Netherlands & High income: OECD & Russian Federation & Upper middle income \\
\hline Sweden & High income: OECD & Egypt, Arab Rep. & Lower middle income \\
\hline Canada & High income: OECD & India & Lower middle income \\
\hline Finland & High income: OECD & Indonesia & Lower middle income \\
\hline Portugal & High income: OECD & Pakistan & Lower middle income \\
\hline Spain & High income: OECD & Philippines & Lower middle income \\
\hline Australia & High income: OECD & Thailand & Lower middle income \\
\hline New Zealand & High income: OECD & Vietnam & Lower middle income \\
\hline Israel & High income: OECD & $\begin{array}{l}\text { China }+ \text { Hong } \\
\text { Kong }\end{array}$ & Lower middle income \\
\hline Korea, Rep. & High income: OECD & Bangladesh & Low income \\
\hline Hungary & High income: OECD & Myanmar & Low income \\
\hline Poland & High income: OECD & Lao PDR & Low income \\
\hline Singapore & High income: non-OECD & Cambodia & Low income \\
\hline Taiwan & High income & & \\
\hline
\end{tabular}

